Journal of Applied Veterinary Sciences, 6 (3): 60 -69 ( July 2021).

ISSN: Online: 2090-3308, Print: 1687-4072

Journal homepage : https://javs.journals.ekb.eg

\title{
Exploring antimicrobial activity of Lactobacillus spp. (probiotics) isolated from raw cow's milk against Staphylococcus aureus causing bovine mastitis
}

\author{
Kamel $^{1}$, H. M., Armanious ${ }^{2}$, W., Morgan ${ }^{3}$, S., Ebtsam E.Z. Kotb ${ }^{4 *}$ \\ ${ }^{1}$ Directorate of Veterinary Medicine, Giza Governorate, Ministry of Agriculture and Land Reclamation, Egypt. \\ ${ }^{2}$ Department of microbiology, Faculty of veterinary medicine, Cairo University, Egypt. \\ ${ }^{3}$ Department of Food hygiene and control, Faculty of veterinary medicine, Cairo University, Egypt. \\ ${ }^{4}$ Department of Udder Health and Neonatal Diseases, Animal Reproduction Research Institute, Egypt. \\ *Corresponding Author, Ebtsam E.Z. Kotb; E-Mail: dekotb@yahoo.com
}

\begin{abstract}
Bovine mastitis is a costly disease in the dairy farms globally. The control of such disease is generally based on the prevention by the strict hygienic measures during milking. Other approaches include vaccination and the application of antibiotics. Regardless to these procedures, mastitis is not entirely under the control, thus increasing the need for alternative tactics. This study was conducted to isolate and identify lactic acid bacteria (LAB) from fresh cow's milk which possess antibacterial activity that could be used for mastitis control. 146 isolates were recognized as (LAB) from105 milk tanks samples after being cultured anaerobically on de Man, Rogosa and Sharpe (MRS) agar plates for 48 hours at $37{ }^{\circ} \mathrm{C}$ and identified by general bacteriological investigation. Afterwards, 24 isolates were identified to belong to genus Lactobacillus using polymerase chain reaction (PCR), and for species level recognition MALDI-TOF MS (matrix-assisted laser desorption ionization-time of flight mass spectrometry) was used resulted in : L. fermentum (5), L. brevis (3), L. plantarum (4), L. paracasei (2), L. rhamnosus (3), L. pentosus (2), L. casei (3), L. raffinolactis (1) and L. mesenteroids (1). The antimicrobial activity of these strains against one of the major mastitis pathogens, S. aureus, was detected by the agar well diffusion assay and the modified double layer method, where L. casei, L. fermentum and L. plantarum possess the most inhibiting effect besides they have no hemolytic nor gelatin liquefaction activity when their safety profiles were evaluated. The result of the antibiotic susceptibility test revealed that these isolates were resistant to vancomycin (VA), neomycin $(\mathrm{N})$ and gentamycin $(\mathrm{CN})$. On the other hands, they were highly sensitive to amoxicillin clavulanic acid (AMC), Levofloxacin (LEV), tetracycline (TE) and penicillin (P). The study suggests that $L$. casei, L. fermentum and L. plantarum are perfect candidates to be used as probiotics to help in preventing and controlling bovine mastitis caused by Staphylococcus aureus as they were proven to be safe and have antimicrobial activity against the organism.
\end{abstract}

Keywords: Bovine mastitis, Lactobacillus, MALDI-TOF MS, probiotics, S. aureus.

J. Appl. Vet. Sci., 6 (3): 60 -69.

\section{INTRODUCTION}

For many years probiotics have been studied for their beneficial effects on human and animal health (Reid et al., 2006 and Behnsen et al., 2013). Probiotics contribute to preserve the stability of natural microbiota of the host niche by competing with the pathogen for tissue colonization, controlling virulence expression or stimulating the innate immune system
Original Article:

DOI:https://dx.doi.org/10.21608/javs.2 $\underline{021.79310 .1083}$

Received:05 June, 2021.

Accepted:09 July, 2021.

Published in July, 2021.

This is an open access article under the term of the Creative Commons Attribution 4.0 (CC BY) International License. To view a copy of this license, visit:

http://creativecommons.org/licenses/by/4.0/ 
Nowadays the administration of probiotics is considered as an alternative method for the prevention and treatment of infections. It is believed that preventive treatment with probiotic product could decrease the usage of antibiotics. Probiotics do not cause negative impact on gut microflora (Serikbayeva et al., 2005 and Reid et al., 2006) and provide 'healthy bacteria' include Lactobacillus strains, Bifidobacterium, and Enterococcus faecium (Shirley and Jean 2010). In animal production sector, probiotic bacteria have been used in the feeds or drinking water of cattle, poultry, pigs, and fish, to improve their performance (Dowarah, R. et al., 2017 and ViecoSaiz, N. et al., 2019).

Also, the use of probiotics has gained attention to combat bovine mastitis (an inflammatory condition of the mammary gland) which usually resulted from bacterial infection causing massive economic losses in the dairy farms and dairy industries (Contreras and Rodriguez, 2011 and Le Marechal et al., 2011). Lactic acid bacteria (LAB) can afford protection against mastitis when they are used in diets, teat dip, and intramammary inoculation due to their strong immunomodulatory effect (Rainard and Foucras, 2018). LAB can form a protective biofilm in the udder which inhibits the growth of pathogens and prevent mastitis (Wallis et al., 2018). The bovine mammary microbiota was investigated to identify microorganisms with inhibitory properties against mastitis pathogens (Espeche et al., 2012).

The world health organization (WHO) and food and agriculture organization of the United Nations (FAO) have stated that there is satisfactory scientific evidence to indicate that specific strains are safe and have the potential to provide the health benefits (FAO/WHO, 2001). The aim of this work is the evaluation of the antimicrobial activity of lactobacilli isolated from fresh cow's milk against $S$. aureus which is a major mastitis pathogen

\section{MATERIAL AND METHODS}

\section{Materials:}

Milk samples collection according to Oliver $\boldsymbol{e t}$ al., (2004). The 105 tanks milk samples were collected under complete aseptic conditions into sterile bottles and then transported to the laboratory for investigation within 2 hours from dairy farms applying machine milking.

\section{Method:}

\section{Isolation of lactic acid bacteria:}

On MRS broth and agar media (Hi-Media, India), incubated anaerobically in an Anaerobic GasPack system (Oxoid) for 48 hours at $37^{\circ} \mathrm{C}$ to obtain single discrete colonies (Halder et al., 2015)

\section{Identification of bacterial isolates:}

\subsection{Phenotypic identification:}

The purified bacterial colonies were identified by checking their macroscopic and microscopic appearance, biochemical reactions (catalase and oxidase) and motility test as described in Bergey's manual of systematic bacteriology (Logan and De Vos, 2009).

\subsection{Molecular identification}

Amplification of 16S rRNA gene was performed by a modified method of Massol-Deya $\boldsymbol{e t}$ al., (1995).

\subsubsection{DNA extraction}

A loopful of overnight grown cells was transferred to $50 \mu \mathrm{l}$ TE buffer and boiled for $5 \mathrm{~min}$, then centrifuged at $10,000 \mathrm{rpm}$ for $10 \mathrm{~min}$ at $4^{\circ} \mathrm{C}$. After that, $1 \mu \mathrm{l}$ of supernatant was used as template for PCR reaction.

\subsubsection{Amplification of $16 \mathrm{~S}$ rDNA Region by Polymerase Chain Reaction (PCR)}

PCR was performed by using the Premix Taq (Ex Taq Version, Takara, Japan) according to instruction manual. A pair of flanking sequences was used for primer binding sites to partially amplify target 16S rRNA gene from the bacterial isolates, primers are LbLMA1-rev (5'-CTC AAA ACT AAA CAAAGT TTC-3') and R16-1 (5'-CTT GTA CAC ACC GCC CGT CA-3') ( Dubernet et al., 2002), Lactobacillus acidophilus La-5 was the reference strain used in this PCR methode. DNA fragments were amplified as follows: Amplification reactions were executed in total volume of $25 \mu \mathrm{l}$ containing $1 \mu \mathrm{l}$ of each primer (10pmol), $12.5 \mu \mathrm{l}$ of Premix Taq and $1 \mu \mathrm{l}$ of DNA template. PCR was carried out in genius model FGENO2TD thermal cycler (Techne, England).

The PCR conditions were accustomed to initial denaturation for $5 \mathrm{~min}$ at $95^{\circ} \mathrm{C}$ then 30 cycles designed as (Denaturation:30 sec at $95^{\circ} \mathrm{C}$, annealing: $30 \mathrm{sec}$ at $55^{\circ} \mathrm{C}$, and extension: $30 \mathrm{sec}$ at $72^{\circ} \mathrm{C}$ ), and finally $7 \mathrm{~min}$ at $72^{\circ} \mathrm{C}$. The amplified products were subjected to electrophoresis in $1 \%$ agarose gels (Elec trophoresis grade, Invitrogen) in TAE buffer ( $40 \mathrm{mM}$ Tris acetate, $1 \mathrm{mM}$ EDTA, pH 8.2). Gels were stained with ethidium bromide ( $5 \mathrm{Wg} \mathrm{ml} 31$ ) and visualised by Gel Documentation system. (InGenius 3).

\subsection{Identification using MALDI-TOF MS:}

Pure cultures were identified to the species level using MALDI-TOF MS method. The samples were automatically analyzed using a MALDI-TOF mass spectrometry (Bruker, Germany) running Flexcontrol 3.4 software. The mass spectra of the tested samples were adjusted using the Bruker's bacterial test 


\section{Exploring antimicrobial activity of Lactobacillus spp. ......}

standard (Bruker Daltonics) as described by Nacef $\boldsymbol{e t}$ al., (2016).

\section{Evaluation of probiotic activity:}

3.1. Preparation of cell free supernatant (CFS):

Lactobacilli strains were cultivated in MRS broth for $48 \mathrm{~h}$ at $37^{\circ} \mathrm{C}$. CFS was obtained by centrifuging the culture $\left(10000 \mathrm{rpm}, 10 \mathrm{~min}, 4^{\circ} \mathrm{C}\right)$ followed by filtration of the supernatant through a 0.2 $\mu \mathrm{m}$ pore size filter (Nowroozi and Mirzaii, 2004).

\subsection{Well diffusion assay:}

An overnight culture of bovine mastitis $S$. aureus (kindly provided by DR. Ebtsam Kotb, ARRI) was swabbed on the surface of nutrient agar plates (1.5 $\mathrm{x} 10^{8} \mathrm{CFU} / \mathrm{ml}$ ) where wells (of $6 \mathrm{~mm}$ diameter) were cut off, bottom sealed with 2 drops of soft agar and CFS $(100 \mu \mathrm{L} /$ well $)$ of the isolated lactobacilli were loaded in the wells marked properly with the isolates' names, plates were left to dry then incubated for 24 hours at $37^{\circ} \mathrm{C}$. After incubation the inhibition zone was recorded, interpreted as weak inhibition $(\leq 10) \mathrm{mm}$, moderate inhibition (11-14) $\mathrm{mm}$ and strong inhibition $(\geq 15) \mathrm{mm}$. The tests were performed in triplicates and the data were represented with mean \pm SD, (Mami $\boldsymbol{e t}$ al., 2008 and Halder et al., 2017).

\subsection{Modified double layer method according to Soleimani et al., (2010):}

An overnight culture of each probiotic Lactobacillus in MRS broth at $37^{\circ} \mathrm{C}$ was prepared. 100 $\mu \mathrm{l}$ of each probiotic Lactobacillus culture $\left(1.5 \times 10^{8}\right.$ $\mathrm{CFU} / \mathrm{ml}$ ) was spotted onto the surface of MRS agar and incubated for $48 \mathrm{~h}$ at $37^{\circ} \mathrm{C}$ anaerobically. The plates of MRS agar containing lactobacilli spots were overlaid with $15 \mathrm{ml}$ melted Muller Hinton agar and allowed to solidify. $100 \mu \mathrm{l}$ of BM S. aureus individually streaked by swab over the entire agar surface. The plates were incubated for $24 \mathrm{~h}$ at $37^{\circ} \mathrm{C}$. After incubation, the zone diameter of inhibition (ZDI) values were measured and interpreted as recorded by Shokryazdan $\boldsymbol{e t}$ al., (2014) where the ZDI $<10 \mathrm{~mm}, 10-20 \mathrm{~mm}$ and $>20$ $\mathrm{mm}$ were considered as weak, moderate and strong inhibitions, respectively.

\section{Evaluation of safety profile of isolated lactobacilli:}

Only Isolates with antibacterial activity against $S$. aureus were checked for their safety profiles using the following techniques:

\subsection{Hemolytic Activity :}

With some modification, MRS agar was used as a blood base for hemolytic activity assessment. The plates were observed for the formation of any clear zones ( $\beta$-hemolysis), greenish hemolytic zones $(\alpha-$ hemolysis), or no such zones ( $\gamma$-hemolysis) around the Lactobacillus colonies (Halder et al., 2017).

\subsection{Gelatin hydrolysis test:}

To detect the ability of an organism to produce gelatinase (proteolytic enzyme) that liquefy gelatin (Tille and Forbes, 2014).

\subsection{Antibiotic susceptibility test:}

The antibiotic susceptibility test was performed following disc diffusion method as described by Bauer et al., (1966). The isolated strains were tested for their resistance against 8 antibiotics. The studied antibiotics

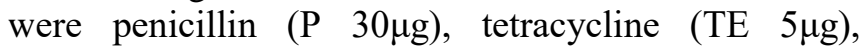

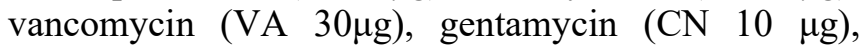

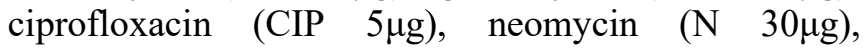
amoxicillin/ clavulinic acid (AMC 30 $\mathrm{gg}$ ) and

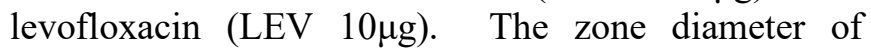
inhibition (ZDI) obtained around the antibiotic disc were recorded, and isolates were regarded as sensitive (ZDI; $\geq 21 \mathrm{~mm}$ ), moderate (ZDI; $16-20 \mathrm{~mm}$ ), or resistant (ZDI; $\leq 15 \mathrm{~mm}$ ), (Vlkova, et al., 2006 and Liasi, et al., 2009).

\section{RESULTS}

\section{Phenotypic identification:}

One hundred- forty-six (146) isolates were identified as lactic acid bacteria (LAB) from 105 milk tanks samples, table 1 . The isolated LAB appeared macroscopically as small to medium size smooth colonies white or creamy in color, Fig. 1 and microscopically they were Gram positive, non-spore forming rods or cocci varying in length and thickness, single, paired or may be in chains, Fig. 2. All were catalase, oxidase negative and non-motile.

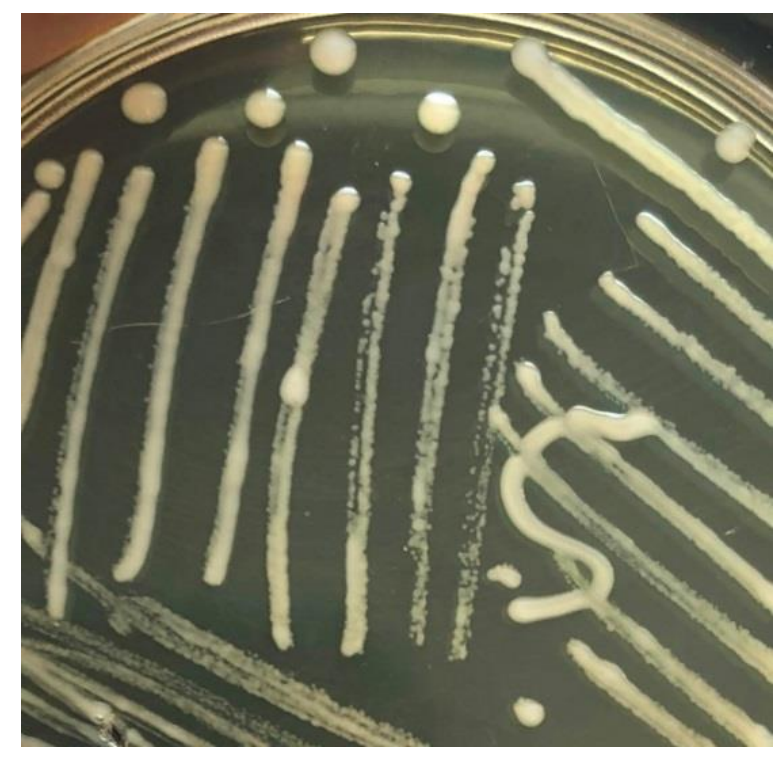

Fig. 1: LAB on MRS agar plates 


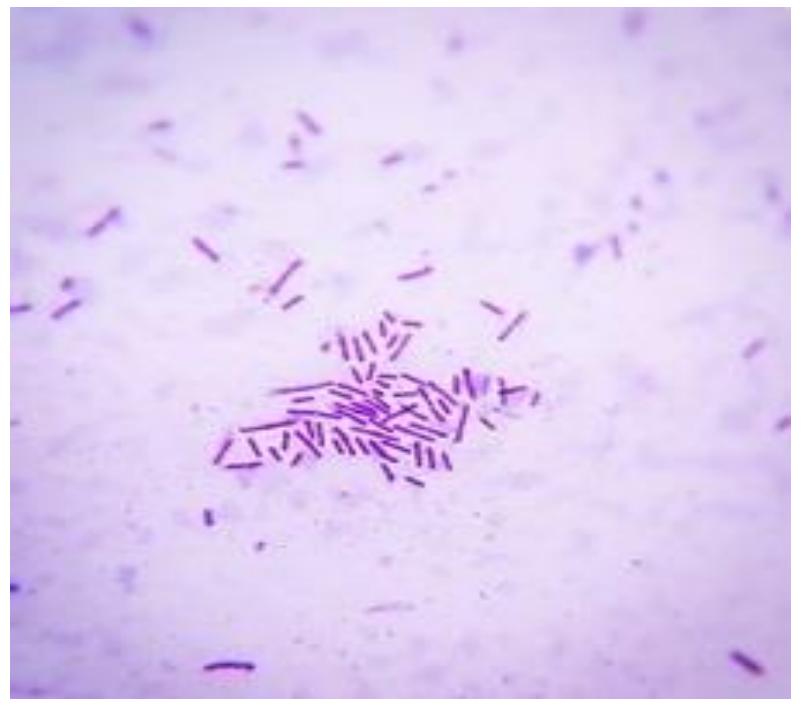

Fig. 2: Gram positive rods

Table 1: Bacteriological isolates from milk samples

\begin{tabular}{|c|c|c|c|}
\hline \multirow{2}{*}{$\begin{array}{c}\text { No. of milk } \\
\text { samples }\end{array}$} & \multicolumn{2}{|c|}{$\begin{array}{c}\text { LAB (lactic acid } \\
\text { bacteria) }\end{array}$} & \multirow{2}{*}{ Total } \\
\cline { 2 - 3 } & Rods & Cocci & \\
\hline 105 & 27 & 119 & 146 \\
\hline
\end{tabular}

\section{Molecular identification:}

Rod-shaped isolates were introduced to (PCR) and were identified to the genus level using PCR method revealing that 24 isolates belong to genus Lactobacillus. PCR products presented a $250 \mathrm{bp}$ amplicon approximately as show in Fig. 3 and table 2.

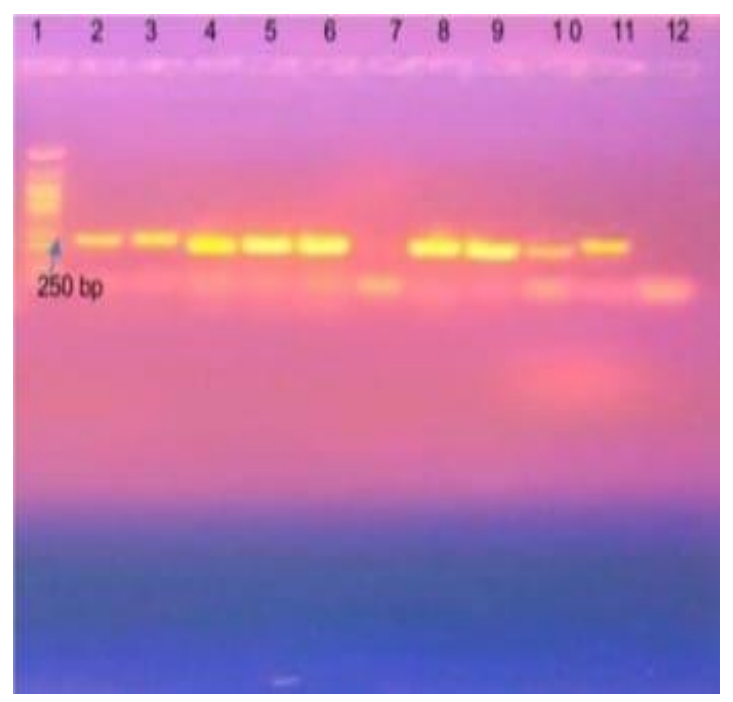

Fig. 3: PCR ampilification products, lane 1: $100 \mathrm{bp}$ ladder, lanes from (3-6) and from (8-11) lactobacilli, lane 2: positive control (Lactobacillus acidophilus La-5), lane 12: negative control, lane 7: negative result.

\section{Identification using MALDI-TOF MS:}

The isolates were successfully identified by Matrix-assisted laser desorption/ionization-time of flight (MALDI-TOF) mass spectrometry to species levels as shown in table. 2 .

Table 2: Results of PCR and MALDI-TOF identification

\begin{tabular}{|c|c|c|}
\hline $\begin{array}{l}\text { Isolate } \\
\text { serial }\end{array}$ & $\begin{array}{c}\text { PCR } \\
\text { results }\end{array}$ & $\begin{array}{c}\text { MALDI-TOF } \\
\text { MS results }\end{array}$ \\
\hline $\mathrm{B}, \mathrm{O}, \mathrm{G}, \mathrm{S}, \mathrm{W}$ & $\begin{array}{c}\text { Lactobacillus } \\
\text { species }\end{array}$ & L. fermentum \\
\hline $\mathrm{A}, \mathrm{U}, \mathrm{N}$ & $\begin{array}{c}\text { Lactobacillus } \\
\text { species }\end{array}$ & L. brevis \\
\hline $\mathrm{Y}, \mathrm{V}, \mathrm{M}, \mathrm{C}$ & $\begin{array}{c}\text { Lactobacillus } \\
\text { species }\end{array}$ & L. plantarum \\
\hline $\mathrm{D}, \mathrm{I}$ & $\begin{array}{c}\text { Lactobacillus } \\
\text { species }\end{array}$ & L. paracasei \\
\hline $\mathrm{R}, \mathrm{F}, \mathrm{T}$ & $\begin{array}{c}\text { Lactobacillus } \\
\text { species }\end{array}$ & L. rhamnosus \\
\hline $\mathrm{P}, \mathrm{X}$ & $\begin{array}{c}\text { Lactobacillus } \\
\text { species }\end{array}$ & L. pentosus \\
\hline $\mathrm{Q}, \mathrm{Z}, \mathrm{J}$ & $\begin{array}{c}\text { Lactobacillus } \\
\text { species }\end{array}$ & L. casei \\
\hline $\mathrm{K}$ & $\begin{array}{c}\text { Lactobacillus } \\
\text { species }\end{array}$ & L.raffinolactis \\
\hline $\mathrm{L}$ & $\begin{array}{c}\text { Lactobacillus } \\
\text { species }\end{array}$ & L.mesenteroides \\
\hline
\end{tabular}

4. Evaluation of antimicrobial activity of probiotic: 4.1. Agar well diffusion assay:

L. casei, L. plantarum and L. fermentum showed the highest inhibition while $L$. brevis, $L$. mesenteriods, L. raffinolactis and $L$. paracasei showed weak or no inhibition against $S$. aureus, Table 3 and Fig. 4.

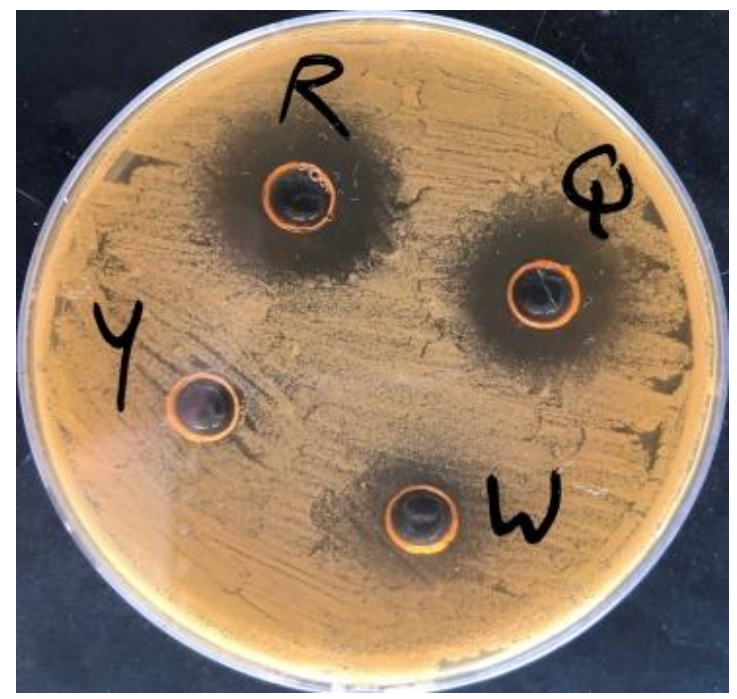

Fig. 4: Clear zones around the wells loaded with Lactobacillus cell free supernatant representing the inhibiting activity of lactobacillus against $S$. aureus. $\mathrm{R}=L$. rhamnosus, $\mathrm{Q}=L$. case, $\mathrm{W}=L$. fermentum, $\mathrm{Y}=L$. plantarum. 
Table 3: Agar well diffusion assay, results represent the mean \pm standard deviation of three replicates.

\begin{tabular}{|c|c|c|c|c|c|}
\hline $\begin{array}{c}\text { Isolate } \\
\text { serial }\end{array}$ & Isolate & $\begin{array}{l}\text { S. aureus inhibition } \\
\text { zone }(\mathrm{mm})\end{array}$ & Isolate serial & Isolate & $\begin{array}{c}\text { S. aureus inhibition } \\
\text { zone (mm) }\end{array}$ \\
\hline $\mathrm{P}$ & L. pentosus & $(-\mathrm{ve})$ & $\mathrm{Z}$ & L. casei & $(-)$ \\
\hline $\mathrm{X}$ & L. pentosus & ++ & $\mathrm{Q}$ & L. casei & +++ \\
\hline $\mathrm{V}$ & L. plantarum & +++ & $\mathrm{J}$ & L. casei & $(-)$ \\
\hline $\mathrm{Y}$ & L. plantarum & $(-)$ & $\mathrm{L}$ & L. mesenteroide & $(-)$ \\
\hline $\mathrm{M}$ & L. plantarum & +++ & $\mathrm{S}$ & L. fermentum & $(-)$ \\
\hline $\mathrm{C}$ & L. plantarum & $(-)$ & $\mathrm{W}$ & L. fermentum & +++ \\
\hline $\mathrm{R}$ & L. rhamnosus & +++ & $\mathrm{O}$ & L. fermentum & +++ \\
\hline $\mathrm{F}$ & L. rhamnosus & $(-)$ & $\mathrm{G}$ & L. fermentum & ++ \\
\hline $\mathrm{T}$ & L. rhamnosus & ++ & $\mathrm{B}$ & L. fermentum & $(-)$ \\
\hline $\mathrm{A}$ & L. brevis & + & $\mathrm{K}$ & L. raffinolactis & $(-)$ \\
\hline $\mathrm{U}$ & L. brevis & + & $\mathrm{I}$ & L. paracasei & + \\
\hline $\mathrm{N}$ & L. brevis & $(-)$ & $\mathrm{D}$ & L. paracasei & $(-)$ \\
\hline
\end{tabular}

Degree of inhibition: Week (+), moderate $(++)$, strong (+++), no activity (-)

Table 4: Modified double layer method, antimicrobial activity of Lactobacillus against S. aureus.

\begin{tabular}{|c|c|c|c|c|c|}
\hline $\begin{array}{c}\text { Isolate } \\
\text { serial }\end{array}$ & Isolate & $\begin{array}{l}\text { S. aureus inhibition } \\
\text { zone }(\mathrm{mm})\end{array}$ & Isolate serial & Isolate & $\begin{array}{l}\text { S. aureus } \text { inhibition } \\
\text { zone (mm) }\end{array}$ \\
\hline $\mathrm{P}$ & L. pentosus & $(-)$ & $\mathrm{Q}$ & L. casei & +++ \\
\hline $\mathrm{X}$ & L. pentosus & ++ & $\mathrm{Z}$ & L. casei & $(-)$ \\
\hline $\mathrm{V}$ & L. plantarum & +++ & $\mathrm{J}$ & L. casei & $(-)$ \\
\hline $\mathrm{M}$ & L. plantarum & +++ & $\mathrm{L}$ & L. mesenteriods & $(-)$ \\
\hline $\mathrm{Y}$ & L. plantarum & + & $\mathrm{S}$ & L. fermentum & $(-)$ \\
\hline $\mathrm{C}$ & L. plantarum & $(-)$ & $\mathrm{W}$ & L. fermentum & +++ \\
\hline $\mathrm{R}$ & $\begin{array}{c}\text { L. } \\
\text { rhamnosus }\end{array}$ & +++ & $\mathrm{O}$ & L. fermentum & +++ \\
\hline $\mathrm{T}$ & $\begin{array}{c}\text { L. } \\
\text { rhamnosus }\end{array}$ & ++ & $\mathrm{G}$ & L. fermentum & ++ \\
\hline $\mathrm{F}$ & $\begin{array}{c}\text { L. } \\
\text { rhamnosus }\end{array}$ & $(-)$ & $\mathrm{B}$ & L. fermentum & $(-)$ \\
\hline $\mathrm{A}$ & L. brevis & + & $\mathrm{K}$ & L. raffinolactis & $(-)$ \\
\hline $\mathrm{U}$ & L. brevis & + & $\mathrm{I}$ & L. paracasei & + \\
\hline $\mathrm{N}$ & L. brevis & $(-)$ & $\mathrm{D}$ & L. paracasei & + \\
\hline
\end{tabular}

Degree of inhibition: Week (+), moderate $(++)$, strong (+++), no activity (-) 


\subsection{Modified double layer method:}

$L$. casei, L. rhamnosus, $L$. plantarum and $L$. fermentum have the highest inhibitory effect on $S$. aureus, while $L$. brevis, $L$. mesenteriods, $L$. raffinolactis and $L$. paracasei showed weak or no inhibiting, shown in the table 4 and Fig. 5.

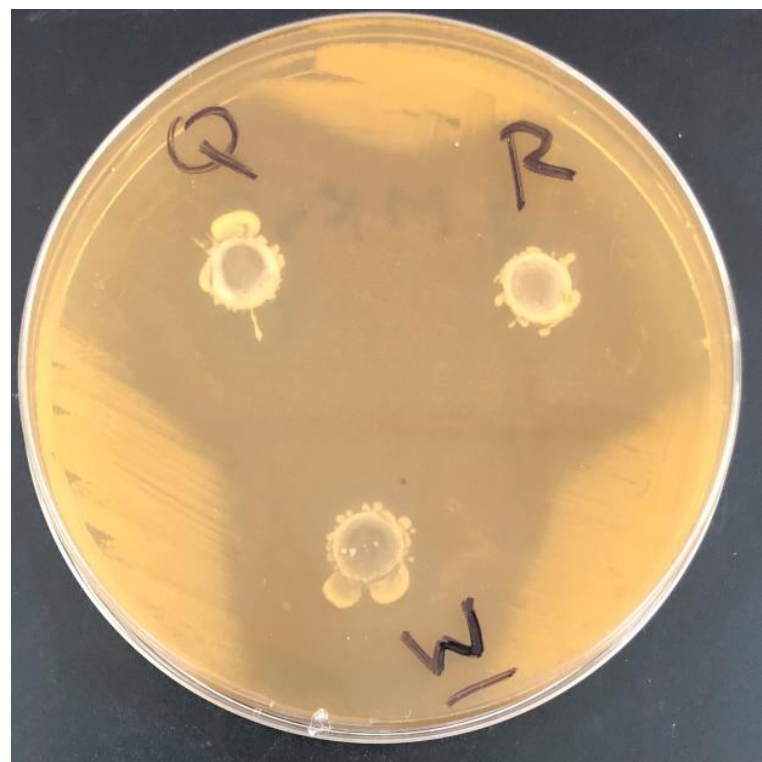

Fig. 5: Modified double layer method. Clear zones around the wells containing Lactobacillus growth representing the inhibiting activity of lactobacillus against $S$. aureus. $\mathrm{R}=L$. rhamnosus, $\mathrm{Q}=L$. casei, $\mathrm{W}=L$. fermentum.

\section{Evaluation of safety profile of isolated lactobacilli:}

Isolates that showed inhibitory activity against the test subject ( $S$. aureus) were checked for their safety by detecting their hemolytic activity, gelatin hydrolysis and antibiotic susceptibility.

\subsection{Hemolytic Activity:}

The isolated strains that showed inhibitory activity found to be non-hemolytic, as they didn't show any clear or greenish zones around the colonies that were grown on MRS blood agar plates (Fig. 6).

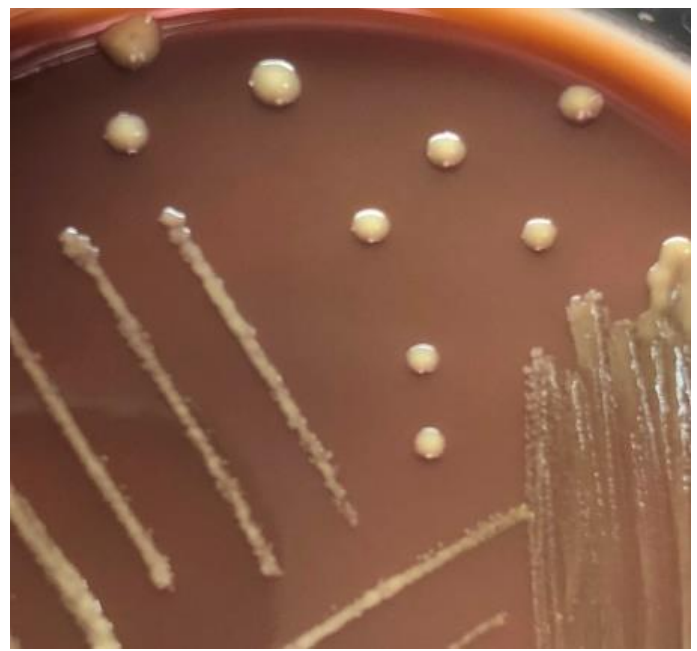

Fig. 6: Lactobacilli colonies on MRS blood agar plates showing $\gamma$-hemolysis.

\subsection{Gelatin hydrolysis:}

All of the isolated strains that showed inhibitory activity against $S$. aureus lack the ability to liquefy gelatin

\subsection{Antibiotic susceptibility test:}

The result of the antibiotic susceptibility test revealed that all the Lactobacillus isolates showed resistance to vancomycin (VA), neomycin (N) and gentamycin $(\mathrm{CN})$, on the other hand, they were sensitive to amoxicillin clavulanic acid (AMC), Levofloxacin (LEV), tetracycline (TE) and penicillin $(\mathrm{P})$ as shown in the Table 5, and Fig. 7.

Table 5: Antibiotic susceptibility test results

\begin{tabular}{|c|c|c|c|c|c|c|c|c|c|}
\hline \multirow[b]{2}{*}{$\begin{array}{l}\text { Is solate } \\
\text { serial }\end{array}$} & \multirow{2}{*}{ isolate } & \multicolumn{8}{|c|}{$\begin{array}{l}\text { Diameter of Zone of inhibition in } \\
\text { millimeter(mm) }\end{array}$} \\
\hline & & 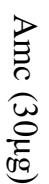 & 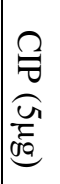 & 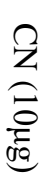 & 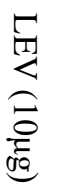 & 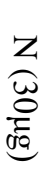 & 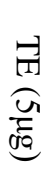 & 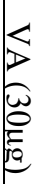 & 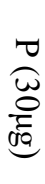 \\
\hline$X$ & L. pentosus & $S$ & $\mathrm{R}$ & $\mathrm{R}$ & $\mathrm{R}$ & $\mathrm{R}$ & $\mathrm{R}$ & $\mathrm{R}$ & $\mathrm{S}$ \\
\hline $\mathrm{M}$ & $\begin{array}{l}\text { L. } \\
\text { plantarum }\end{array}$ & $S$ & $\mathrm{R}$ & $\mathrm{R}$ & $\mathrm{R}$ & $\mathrm{R}$ & $\mathrm{R}$ & $\mathrm{R}$ & $\mathrm{S}$ \\
\hline $\mathrm{V}$ & $\begin{array}{l}\text { L. } \\
\text { plantarum }\end{array}$ & $S$ & $\mathrm{R}$ & $\mathrm{R}$ & $\mathrm{R}$ & $\mathrm{R}$ & $\mathrm{R}$ & $\mathrm{R}$ & $\mathrm{S}$ \\
\hline $\mathrm{R}$ & $\begin{array}{l}\text { L. } \\
\text { rhamnosus }\end{array}$ & $S$ & M & $\mathrm{R}$ & S & $\mathrm{R}$ & S & $\mathrm{R}$ & $\mathrm{S}$ \\
\hline $\mathrm{T}$ & $\begin{array}{l}\text { L. } \\
\text { rhamnosus }\end{array}$ & $S$ & $\mathrm{M}$ & $\mathrm{R}$ & $S$ & $\mathrm{R}$ & $\mathrm{S}$ & $\mathrm{R}$ & $\mathrm{S}$ \\
\hline $\mathrm{Q}$ & L. casei & $S$ & $\mathrm{M}$ & $\mathrm{R}$ & $S$ & $\mathrm{R}$ & $S$ & $\mathrm{R}$ & $S$ \\
\hline W & $\begin{array}{l}\text { L. } \\
\text { fermentum }\end{array}$ & $S$ & $\mathrm{R}$ & $\mathrm{R}$ & M & $\mathrm{R}$ & $\mathrm{S}$ & $\mathrm{R}$ & $\mathrm{S}$ \\
\hline $\mathrm{O}$ & $\begin{array}{l}\text { L. } \\
\text { fermentum }\end{array}$ & $S$ & $\mathrm{R}$ & $\mathrm{R}$ & $\mathrm{M}$ & $\mathrm{R}$ & $S$ & $\mathrm{R}$ & $\mathrm{S}$ \\
\hline
\end{tabular}

$\mathrm{Amc}=$ amoxicillin clavulanic acid, $\mathrm{CIP}=$ ciprofloxacin, $\mathrm{CN}=$ gentamicin, $\mathrm{LEV}=$ Levofloxacin, $\mathrm{N}=$ neomycin, $\mathrm{TE}=$ tetracycline, $\mathrm{VA}=$ vancomycin, $\mathrm{P}=$ penicillin, Sensitive $=\mathrm{S}$, moderate $=\mathrm{M}$, resistant $=\mathrm{R}$.

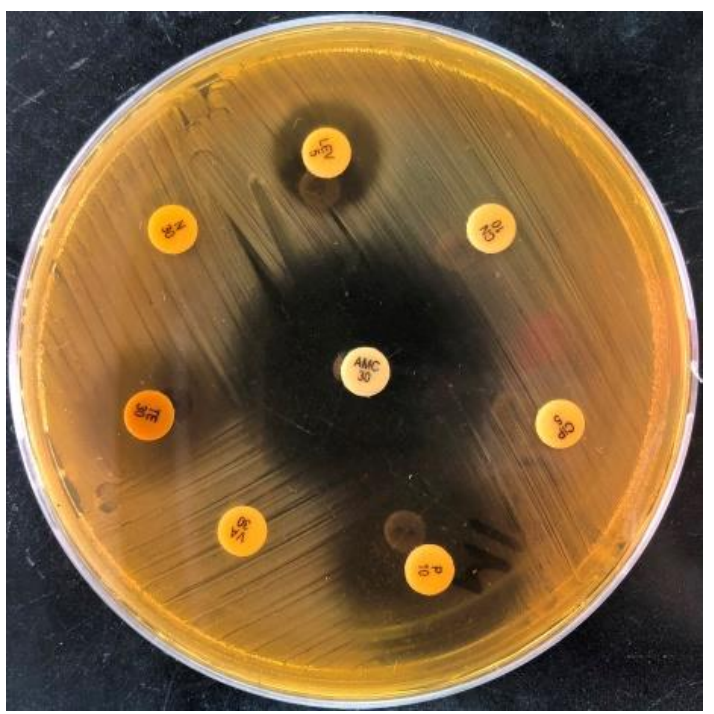

Fig. 7: Antibiotic susceptibility test for L. plantarum, Inhibition zones around antibiotic disc 


\section{DISCUSSION}

It has become a popular theory to use probiotics for their beneficial effect in recent years, where researchers are studying how lactobacilli interact and affect their host. (Reardon, 2014). Moreover; the isolation and screening of lactobacilli from numerous natural sources is a successful way to develop new probiotic strains with valuable medicinal significance (Halder et al., 2017). So, this study highlights the detection of antibacterial activity of Lactobacillus spp. isolated and identified from fresh cow's milk against $S$. aureus which is a major mastitis pathogen, and studied their safety profiles. A total of 146 isolates were identified phenotypically and biochemically as lactic acid bacteria (LAB) from 105 tanks milk as shown in table (1) after being cultured on MRS agar plates and incubated for 48 hours anaerobically depending on the phenotypic and biochemical features.

Our results were similar to those recorded by Touret et al., (2018); Mostafa et al., (2019); Vanniyasingam et al., (2019) and Jobby et al., (2020) whom were able to isolate strains that match the phenotypic and biochemical features of LAB. Relying on conventional methods based on phenotypic, physiological and biochemical criteria to identify LAB is complex and time-consuming approaches and can underestimate the microbiological diversity of a bacterial community (Ercolini et al., 2001).

In contrast, advanced methods as the nucleic acid-based molecular methods have been recognized to be prevailing tools for the identification of bacterial isolates, and that motivated researchers to give attention to molecular biology applications for the differentiation and rapid detection of LAB (Coeuret $\boldsymbol{e} t$ al., 2003). So, to confirm the genus identification of the isolates we applied PCR technique which helped to identify the lactobacilli at the genus levels as 24 LAB isolates were successfully identified to belong to genus Lactobacillus with the aid of genus-specific primers LbLMA1-rev and R16-1. PCR products presented a $250 \mathrm{bp}$ amplicon approximately as show in table (2) and figure (3). These results were similar to those obtained by Dubernet et al., (2002); Sulieman et al., (2007) and Touret et al., (2018).

As for further identification of the isolated Lactobacillus to species level, MALDI-TOF MS technique was applied. Using MALDI-TOF MS is ought to be suitable for the identification of anaerobic bacteria (Veloo et al., 2011). In the current study, the precise identification of the 24 isolates using MALDITO MS is (3) L. casei strains, (4) L. plantarum strains , (5) L. fermentum strains, (3) L. brevis strains,(1) $L$. mesenteriods strains, (1) L. raffinolactis strains, (2) L. paracasei strains,(2) L. pentosus strains and (3) $L$. rhamnosus strains as shown in table (2).
This technique is considered a fast, costeffective and dependable method (Pavlovic et al., 2013). It is, therefore, considered to be an excellent substitute to biochemical and even molecular methods (Dec et al., 2014; Vithanage et al., 2014). Dušková et al., (2012) stated that the MALDI-TOF MS technique has an advanced success rate $(93 \%)$ than the polymerase chain reaction (PCR) method (77\%) in recognizing Lactobacillus at the species level. Moreover, this approach is becoming a method of choice for defining the genus, species and even subspecies levels of bacterial isolates (Carbonnelle $\boldsymbol{e} t$ al., 2012). Also, this technique can be applied for the identification of other microorganisms as yeasts and fungi isolated from different sources (Chalupova $\boldsymbol{e t}$ al., 2014). Using MALDI-TOF MS, (Nacef et al., 2016); Kanak and Yilmaz, (2018) and Mostafa et al., (2019) were able to identify $L$. rhamnosus, L. brevis, $L$. paracasei, $L$. plantarum $L$. fermentum, $L$. curvatus, $L$. fructivorans and $L$. parabuchneri from different samples including raw milk.

Antimicrobial activity is one of the most significant selection criteria for LAB to be used as a probiotic (Klaenhammer and Kullen, 1999) through the production of inhibitory compounds that antagonize pathogenic bacteria (Nemcova et al., 1997; Jacobsen et al., 1999). Ryan et al., (1999) stated that using non-antibiotic preparations to combat bovine mastitis can diminish the necessity of using antibiotics in treatment of such disease, so the problem of the development of antibiotic resistance pathogens can be solved to a great extent.

In this study, the antimicrobial activity of the isolated lactobacilli against one of the major causes of bovine mastitis, $S$. aureus, was investigated by using two methods, the first method is agar well diffusion assay. The results are shown in table 3 and Fig. 4 as $L$. casei, L. plantarum, L. fermentum and L. rhamnosus showed the highest inhibition. The findings of Mostafa et al., (2019) and Jobby et al., (2020) confirmed these results. The second method was modified double layer method which is shown in table 4 and Fig. 5 where the best inhibition zones against $S$. aureus were achieved in the presence of $L$. casei, $L$. fermentum, L. plantarum and L. rhamnosus. These results were supported with the findings published by Mami et al.,( 2008) and Soleimani et al., (2010).

According to Tambekar et al., (2009) and Halder et al., (2017), this inhibitory effect occurred as a result of the ability of LAB, especially the lactobacilli to product some antimicrobial compounds as organic acids (lactic acid and acetic acid), diacetyl, hydrogen peroxide, bacteriocins and bacteriocin- like substances which were produced during the course of the experiment in addition to their competition for 
nutrients .From the results obtained by the previous two methods to evaluate the antibacterial activity of the isolated lactobacilli, it was clear that the diameter of the inhibition zones in the modified double layer method is nearly twice the diameter of inhibition zones obtained from the agar well diffusion method, this is may be due to the production of inhibitory compounds which were induced more by the existence of the pathogen in contact with the Lactobacillus (as occurred in modified double layer method), in some cases, coculture of LAB with target pathogen can be required for the production of bacteriocin (Cotter et al., 2005 and Touret et al., 2018).

Evaluating the safety profile of a Lactobacillus strain is essential to determine whether if it can to be used as a probiotic or not, it must be non- pathogenic or have any harmful effects to the host, moreover, it should be GRAS and have a beneficial effect to the host (Fuller, 1989).

The probiotic, like lactobacilli, must lack the ability to cause hemolysis as well as liquefaction of gelatin inside host body. The hemolysis and gelatin liquefaction remain on of the major virulence features amongst pathogenic bacteria (Halder et al., 2017).

In the current study, the isolated strains that showed inhibitory activity against $S$. aureus found to be non-hemolytic ( $\gamma$-hemolysis) as shown in figure (6), as they didn't show any clear or greenish zones around the colonies that were grown on MRS blood agar plates, also, they lack the ability to liquefy gelatin. Our results were confirmed by Mami et al., (2008) and Halder et al., (2017). On the other hand Touret et al., (2018) isolated 59 lactobacilli from fermented Sauerkraut and found that only one was $\beta$ - hemolytic, 18 strains showed $\alpha$-hemolysis and 40 isolate presented $\gamma$-hemolysis. Antibiotic susceptibility profile of an isolate can be used to assess its safety to be used as a potential probiotic (Georgieva et al., 2015).

In the present study, the results of the antibiotic susceptibility test showed that all Lactobacillus isolates were resistance to vancomycin (VA), neomycin (N) and gentamycin $(\mathrm{CN}), L$. plantarum and L. pentosus expressed resistance against ciprofloxacin (CIP). On the other hand, all of the isolated strains were sensitive to amoxicillin clavulanic acid (AMC), Levofloxacin (LEV), tetracycline (TE) and penicillin (P). as shown in table (5), figure (7) and (8). Halder et al., (2017); Touret et al., (2018) and Jobby et al., (2020) confirmed our results as all the strains that they isolated were found to be resistant to vancomycin, which is regarded as an intrinsic(nontransferable) or natural resistance. Vanniyasingam $\boldsymbol{e t}$ al.,( 2019) recommended that the variation in results may be due to different sources used for the isolation of LAB and vary from strain and another.
Halder et al., (2015) recommended that lactobacilli strains possessing resistance to antibiotics might be suitable for co-administration along with antibiotics in preventing antibiotic-induced diarrhea and/or in the treatment of intestinal illnesses. Lately, some commercial antibiotics are being manufactured containing a combination of antibiotics in addition to probiotic bacteria as (DOXY-1 L-Dr FORTE by USV Ltd. and AVIDOX-LB by Avalanche pharmaceuticals) which contains Doxycycline and Lactobacillus.

\section{CONCLUSION}

Strains (M, V) L. plantarum, (R) L. rhamnosus, (Q) L. casei and ( $\mathrm{W}, \mathrm{O})$ L. fermentum are good candidates to be used as probiotic regarding to their antibacterial activity against $S$. aureus and their safety profiles. Also, MALDI-TOF MS is considered an accurate, affordable and a rapid method for identification of members of genus Lactobacillus. The use of vancomycin for selective isolation of Lactobacillus. Lactobacilli strains possessing resistance to antibiotics might be suitable for coadministration along with antibiotics to help in controlling bovine mastitis.

\section{Statement of conflict of interests}

All authors declare there is no conflict of interest.

\section{REFERENCES}

BAUER, AW., KIRBY, WM., SHERRIS, JC. AND TURCK, M., 1966. Antibiotic susceptibility testing by a standardized single disk method. Am J Clin Pathol.;45(4):493-496.

BEHNSEN J, DERIU E, SASSONE-CORSI M, AND RAFFATELLU M., 2013. Probiotics: Properties, Examples and Specific Applications. Cold Spring Harb Perspect Med.; 3: a010074. doi: 10.1101/cshperspect. a010074 PMID: 23457295.

CARBONNELlE, E., P. GROHS, H. JACQUIER, N. DAY, S. TENZA, A. DEWAILLY, 0. VISSOUARN, M. ROTTMAN, J.-L. HERRMANN, I. PODGLAJEN AND RASKINE L., 2012. Robustness of two MALDI-TOF mass spectrometry systems for bacterial identification. J. Microbiol. Methods, 89: 133-136. http://dx.doi.org/10.1016/j.mimet. 2012.03.003.

CHALUPOVA, J., M. RAUS, M. SEDLA ŘOVA AND ŠEBELA, M., 2014. Identification of fungal microorganisms by MALDI-TOF mass spectrometry. Biotechnol. Adv., 32: 230-241. http://dx. doi.org/10.1016/j.biotechadv. 2013.11.002.

COEURET, V., DUBERNET, S., BERNARDEAU, M., GUEGUEN, M. AND VERNOUX, J., 2003. Isolation, characterisation and identification of lactobacilli focusing mainly on cheeses and other dairy products. Le Lait, 83(4), 269-306. http://dx.doi.org/10.1051/lait:2003019.

CONTRERAS, GA. AND RODRIGUEZ, JM., 2011 . Mastitis: comparative etiology and epidemiology. J 
Mammary Gland Biol Neoplasia.; 16: 339-356. doi: 10.1007/s10911-011-9234-0 PMID: 21947764

COTTER, P. D., HILL, C. AND ROSS, R. P., 2005. Bacteriocins: developing innate immunity for food. Nat Rev Microbiol. 3(10):777 188 . https://doi.org/10.1038/nrmicro1273PMID: 1620571.1

DEC, M., URBAN-CHMIEL, R., GNAT, S., PUCHALSKI, A. AND WERNICKI, A., 2014. Identification of Lactobacillus strains of goose origin using MALDI-TOF mass spectrometry and 16S-23S rDNA intergenic spacer PCR analysis. Research in Microbiology, 165(3), 190-201. http://dx.doi.org/10.1016/j.resmic.2014.02.003..

DOWARAH, R.; VERMA, A. AND AGARWAL, N., 2017. The Use of Lactobacillus as an Alternative of Antibiotic Growth Promoters in Pigs: A Review. Anim. Nutr. 2017, 3, 1-6.

DUBERNET, S., DESMASURES, N. AND GUEGUEN, M., 2002. A PCR-based method for identifcation of lactobacilli at the genus level. FEMS Microbiology Letters 214 (2002) 271-275.

DUŠKOVÁ, M., ŠEDO, O., KŠICOVÁ, K., ZDRÁHAL, Z. AND KARPÍŠKOVÁ, R., 2012. Identification of lactobacilli isolated from food by genotypic methods and MALDI-TOF MS. International Journal of Food Microbiology, 159(2),

107-114. http://dx.doi.org/10.1016/j.ijfoodmicro.2012.07.029.

ERCOLINI, D., MOSCHETTI, G., BLAIOTTA, G. AND COPPOLA, S., 2001. The potential of a polyphasic PCR dGGE approach in evaluating microbial diversity of natural whey cultures for water buffalo Mozzarella cheese production: bias of culturedependent and culture independent analyses. Systematic and Applied Microbiology, 24(4), 610-617. http:// dx.doi.org/10.1078/0723-2020-00076.

ESPECHE MC, PELLEGRINO M, FROLA I, LARRIESTRA A, BOGNI C. AND NADERMACIAS ME., 2012. Lactic acid bacteria from raw milk as potentially beneficial strains to prevent bovine mastitis. Anaerobe.; 18: 103-109. doi10.1016/j.anaerobe.01.002 PMID: 22261519

EVEN S, BOUCHARD D. AND LE LOIR Y., 2014. Lactic acid bacteria to modulate virulence expression in pathogenic bacteria: An alternative to killing? Interactive probiotics. CRC Press. Boca Raton, USA: Pessione E. (Eds.); pp. 52-80.

FAO/WHO., 2001. Health and Nutritional Properties of Probiotics in Food including Powder Milk with Live Lactic Acid Bacteria. Report of a Joint FAO/WHO Expert Consultation on Evaluation of Health and Nutritional Properties of Probiotics in food Including Powder Milk with Live Lactic Acid Bacteria. American Córdoba Park Hotel Córdoba, Argentina.

FULLER, R., 1989. Probiotics in man and animals. The Journal of Applied Bacteriology 66 (5): 365-378.

GEORGIEVA, R., YOCHEVA, L., TSEROVSKA, L., ZHELEZOVA, G., STEFANOVA, N., ATANASOVA, A., DANGULEVA, A., IVANOVA, G., KARAPETKOV， N., RUMYAN, N. AND KARAIVANOVA, E., 2015. Antimicrobial activity and antibiotic susceptibility of Lactobacillus and Bifidobacterium spp. intended for use as starter and probiotic cultures. Biotechnol Biotechnol Equip 29(1):84-91.

HALDER D, MANDAL S. .2015. Curd Lactobacilli with Probiotic Potentiality. Transl. Biomed., 6: (2-8),1-6.

HALDER, D.; MANDAL, M.; SHIV SEKHAR CHATTERJEE, NISHITH KUMAR PAL AND SHYAMAPADA MANDAL., 2017. Indigenous probiotic lactobacillus isolates presenting antibiotic like activity against human pathogenic bacteria. biomedicines, $\quad 5, \quad 31$; doi:10.3390/biomedicines5020031.

JACOBSEN, C.N., 1999. Screening of probiotic activities of forty-seven strain Lactobacillus ssp.by invitro techniques and evaluation of the colonization ability of five selected strains in umans. Appl. Environ. Microbial., 65: 4949-4956.

JOBBY, R., YASH FLORA, Y., BORA, A., JHA, P., KAWALKAR, H. AND DESAI, N., 2020. Exploring probiotic activity of lactobacillus sp. isolated from indigenous breeds of cattle milk and fecal samples in bhatan village, mh., in. current microbiology. 77:11841190c. doi.org/10.1007/s00284-020-01910-X.

KANAK, E. K. AND YILMAZ, S. O., 2018. Maldi-tof mass spectrometry for the identification and detection of antimicrobial activity of lactic acid bacteria isolated from local cheeses. Food Sci. Technol, Campinas, 39(Suppl. 2): 462-469. Dhttps://doi.org/10.1590/fst.19418.

KLAENHAMMER, T.R., KULLEN, M.J., 1999. Selection and design of probiotics, International journal of food microbiology, 50: 45-57.

LE MARECHAL, C, THIERY, R, VAUTOR, E. AND LE LOIR, Y., 2011. Mastitis impact on technological properties of milk and quality of milk products-a review. Dairy Sci Technol.; 91: 247-282.

LIASI, S. A., AZMI, T. I., HASSAN, M. D., SHUHAIMI, M., ROSFARIZAN, M. AND ARIFF, A. B., 2009. Antimicrobial activity and antibiotic sensitivity of three isolates of lactic acid bacteria from fermented fish product, Budu. Malaysian Journal of Microbiology, Vol 5(1), pp. 33-37.

LOGAN, N.A., DE VOS, P., GENUS I. BACILLUS. IN: DE VOS, P., GARRITY, G.M., JONES, D., KRIEG, N.R., LUDWIG, W., RAINLEY, F.A., SCHLEIFER, K.H. AND WHITMAN, W.B. (EDS.)., 2009. Bergey's Manual of Systematic Bacteriology. Springer Science and Business Media, New York, Vol(3), pp. 21-108

LOURENS-HATTINGH, ANALIE, VILJOEN AND BENNIE, C., 2001. Yogurt as probiotic carrier food. International Dairy Journal. January 2001, Volume (11) 1-2: Pages 1-17.

MAMI A, HENNI JE. AND KIHAL M., 2008. Antimicrobial Activity of Lactobacillus species Isolated from Algerian Raw goat's Milk against Staphylococcus aureus. World J. Dairy \& Food Sci., 3 (2): 39-49.

MASSOL-DEYA, A.A., ODELSON, D.A., HICKEY, R.F. AND TIEDJE, J.M., 1995. Bacterial community fingerprinting of amplified $16 \mathrm{~S}$ and 16-23S ribosomal DNA gene sequences and restriction endonuclease analysis (ARDRA). In: "Molecular Microbial. Ecology Manual", 3.3.2, pp. 289-296. 
MOSTAFA, N. G., GEWAILY, E.M., EL-ZAMIK, F. I. AND ALI, A.S., 2019. Purification and specification of bacteriocin produced by some lactobacillus spp. isolated from food. Zagazig J. Agric. Res., 46: (2), 489-500.

NACEF, M., M. CHEVALIER, S. CHOLLET, D. DRIDER AND C. FLAHAUT, 2016. MALDI-TOF mass spectrometry for the identification of lactic acid bacteria isolated from a French cheese: The Maroilles. Int. J. Food Microbiol., 1-7.

NEMCOVÁ, R., 1997. Criteria for selection of lactobacilli for probiotic use. Vet Med (Praha). 1997 Jan;42(1):1927. Slovak. PMID: 9123779

NOWROOZI, J. AND MIRZAII, M., 2004. Study of Lactobacillus as Probiotic bacteria. Irainian J. Publ. Hlth., 33(2): 1-7.

OLIVER, S., LEWIS, M., GILLESPIE, B., DOWLEN, H.H., JAENICKE, E. AND ROBERTS, R., 2004. Microbiological Procedures for the Diagnosis of Bovine Udder Infection and Determination of Milk Quality.https://www.semanticscholar.org/paper/Microb iological-Procedures-for-the-Diagnosis-of-and-OliverLewis/f7d5c3ba0f4ac879698b51cf5288e51b1eccef94

ÖZCAN, N., EZIN, Ö., AKPOLAT, N., BOZDAĞ, H., METE, M. AND GÜL, K., 2016. Klinik örneklerde saptanan Candida türlerinin MALDI-TOF MS ile tiplendirilmesi. Dicle Medikal Journal, 43(3), 390-394.

PAVLOVIC, M., HUBER, I., KONRAD, R. AND BUSCH, U., 2013. Application of MALDI-TOF MS for the identification of food borne bacteria. The Open Microbiology Journal, 7(1), 135-141. http://dx.doi.org/10.217 4/1874285801307010135. PMid:24358065.

RAINARD P. AND FOUCRAS G., 2018. A critical appraisal of probiotics for mastitis control. Front Vet Sci. 5:251.

REARDON, S. (2014): Microbiome therapy gains market traction. Nature, 509, 269-270.

REID, G., KIM, S. O. AND KOHLER, G. A., 2006. Selecting, testing and understanding probiotic microorganisms. FEMs Immunological Medicinal Microbiology, 46: 149-157.

RYAN, M.P., JACK, R.W., JOSTEN, M. AND JUNG, G., 1999. Extensive posttranslational Modification, Including Serine to D-Alanine Conversion, in the twocomponent lantibiotic, lacticin 3147. J. biol. Chem., 274: 37544-37550.

SENGUPTA, R, ALTERMANN, E., ANDERSON, RC., MCNABB, WC., MOUGHAN, PJ. AND ROY, NC., 2013. The role of cell surface architecture of lactobacilli in host-microbe interactions in the gastrointestinal tract. Mediators Inflame; 2013: 237921. doi: 10.1155/2013/237921 PMID: 23576850 Clin. Infect. Dis. 2010; 50: 1551-1558. doi: 10.1086/652763 PMID: 20455694

SERIKBAYEVA, A., KONUSPAYEVA, G., FAYE, B., LOISEAU, G. AND NARMURATOVA, M., 2005. Probiotic properties of a sour-milk product: shubat from the camel milk. Desertification combat and food safety. IOS Press, p. 187-191.

SHIRLEY, J. C. AND JEAN, F., 2010 . Quick Tips About Using Probiotics with Wildlife in Rehabilitation. www.ewildagain.org
SHOKRYAZDAN, P; SIEO, C.C; KALAVATHY, R; LIANG, J.B; ALITHEEN, N.B; JAHROMI, M.F. AND AHMED, M., 2014. Probiotic potential of Lactobacillus strains with antimicrobial activity against some human pathogenic strains. Biomed. Res. Int., 2, 1

SOLEIMANI, N.A., KERMANSHAHI, R. K., YAKHCHALI, B., AND SATTARI, T. N., 2010. Antagonistic activity of probiotic lactobacilli against Staphylococcus aureus isolated from bovine mastitis. African Journal of Microbiology Research, 4(20), 2169-2173.

SULIEMAN, A.E.; OSAWA, R. AND TSENKOVA, R., 2007. Isolation and identification of lactobacilli from Garris, a Sudanese fermented camel's milk product.research Journal of Microbiology 2(2): 125.

TAMBEKAR, D.H., BHUTADA, S.A., CHOUDHARY, S.D. AND KHOND, M.D., 2009. Assessment of potential probiotic bacteria isolated from milk of domestic animals. J. Appl. Biosci. 15, 815-819.

TILLE, P. M., 2014. Bailey \& Scott's Diagnostic Microbiology (Thirteenth edition.). St. Louis, Missouri: Elsevier.

TOURET, T., OLIVEIRA, M. AND SEMEDOLEMSADDEK, T., 2018. Putative probiotic lactic acid bacteria isolated from sauerkraut fermentations. PLoS ONE13(9): e0203501. https://doi.org/10.1371/journal pone.0203501

VANNIYASINGAM, J.; KAPILAN, R. AND VASANTHARUBA， S., 2019. Isolation and characterization of potential probiotic lactic acid bacteria isolated from cow milk and milk products.

VELOO, A.C.M., WELLING, G.W. AND DEGENER, J.E., 2011. The identification of anaerobic bacteria using MALDI-TOF MS. Anaerobe17: 211-212. Vet. Med., 42: 19-27.

VIECO-SAIZ, N.; BELGUESMIA, Y.; RASPOET, R., AUCLAIR, E.; GANCEL, F.; KEMPF, I. AND DRIDER, D., 2019. Benefits and Inputs from Lactic Acid Bacteria and Their Bacteriocins as Alternatives to Antibiotic Growth Promoters During Food- Animal Production. Front. Microbiol. 10, 57.

VITHANAGE, N. R., YEAGER, T. R., JADHAV, S. R., PALOMBO, E. A., AND DATTA, N., 2014. Comparison of identification systems for psychrotrophic bacteria isolated from raw bovine milk. International Journal of Food Microbiology, 189, 2638. doi.org/10.1016/j. ijfoodmicro.2014.07.023. PMid:25113043.

VLKOVA, E., RADA, V., POPELÁŘOVÁ, P., TROJANOVÁ, I. AND KILLER, J., 2006. Antimicrobial susceptibility of bifidobacteria isolated from gastrointestinal tract of calves. Livestock Science 105,253

WALLIS JK, KROMKER V. AND PADUCH JH., 2018. Biofilm formation and adhesion to bovine udder epithelium of potentially probiotic lactic acid bacteria. AIMS Microbiol. 4(2):209-224.

How to cite this article:

Kamel, H. M. Armanious, W., Morgan, S., Ebtsam and E.Z. Kotb, 2021. Exploring antimicrobial activity of Lactobacillus spp. (probiotics) isolated from raw cow's milk against Staphylococcus aureus causing bovine mastitis. Journal of Applied Veterinary Sciences, 6 (3): $60-69$.

DOI:10.21608/javs.2021.79310.1083 